PUBLIC FINANCIAL/TAX POLICIES FOR SOCIAL

INCLUSION AND THE WORLD OF WORK: A RIDE BETWEEN POST-MODERN VALUES, FACTUAL REALITIES AND THE CONSTITUTIONAL UNIVERSE

\author{
POLÍTICAS PÚBLICAS FINANCEIRAS/TRIBUTÁRIAS DE \\ INCLUSATO SOCLAL E O MUNDO DO TRABALHO: UM PASSEIO \\ ENTRE VALORES PÓS-MODERNOS, REALIDADES REAIS E O \\ UNIVERSO CONSTITUCIONAL
}

\begin{abstract}
Hugo Thamir Rodrigues ${ }^{1}$ Raimar Machado ${ }^{1}$

Recebido em: 05/12/ 2016 Aceito em: 22/12/2016

hugo.thamir@terra.com.br raimar@terra.com.br

Abstract: In contrast to what many people think, the Brazilian State is not characterized as Social. The Republic Constitution defines clearly the economic system as capitalist by considering private property, free initiative, free market competition, and the preservation of the existence of different social classes extremely important; and by establishing a tax system in favors of those who own large incomes and/ or patrimony, mainly the large companies, which, contrasts significantly with the "social function" present throughout the constitutional body. This function allows the implementation of a fairer reality, given the formal impositions of being a "Republic", a "Cooperative federated" entity and a "Democratic State of Law," following the format stablished by the third article. In parallel with the constitutional body, it is noticed the existence of a State which is characterized for being privatized by a neoliberal ideology and for becoming, simultaneously, an autopoietic structure focused on the corporate interests of political and administrative classes that constitute its structure. Regarding the society, it is immersed in the postmodernity values, in selfishness, in individualism and in the pursuit of the type of happiness that is fundamentally based on volatile material goods and ephemeral personal relationships. Such State needs resources to fulfill its original obligations, which must be sought in the pockets of the people who constitute it, seeks its legitimacy based on the principle of solidarity when collecting, managing and applying its values. From these perceptions, it is evident that the Constitution provides sufficient means for the implementation of public policies to seek the effectiveness of social justice. It is also possible to notice that the real obstacles is the State privatization by the neoliberal ideology added to a structure that, aims itself rather than its target public, the Brazilian people, exalting corporatism over the common good. Those obstacles are allied to postmodern values that permeate the society, especially with regard to selfishness, to individualism and to the almost absolute prioritization of happiness pursuit through material goods and superficial personal relationships geared towards economic and financial interests. In order to carry out this article, historical, empirical and inductive methods were used, emphasizing a systemic view of the world of facts and the formal world of constitutional norms.
\end{abstract}

Keywords: Globalization. Social inclusion. Neoliberalism. Public financial and tax policies.

Postmodernity. Solidarity.

Resumo: Contrariando ao pensamento de muitos, o Estado brasileiro não se caracteriza como Social. A Constituição da República claramente define o sistema econômico como capitalista ao dar extrema importância à propriedade privada, à livre iniciativa, à livre concorrência, à preservação da existência de diferentes classes sociais e ao estabelecer um sistema tributário que favorece a quem detém grande renda e/ou patrimônio, fundamentalmente às grandes empresas, o que, de forma bastante acentuada, contrasta com a "função social" presente ao longo do corpo constitucional, função esta que permite, dado as imposições formais de ser uma "República", um ente "federado cooperativo" e um "Estado Democrático de Direito", a implementação de uma realidade mais justa, nos moldes estabelecidos pelo conteúdo do artigo terceiro. Já, paralelamente ao corpo constitucional, percebe-se a existência de um Estado que se caracteriza por ter sido privatizado pela

\footnotetext{
${ }^{1}$ Universidade de Santa Cruz do Sul - UNISC - Santa Cruz do Sul - Rio Grande do Sul - Brasil
} 
ideologia neoliberal e por ter se transformado, concomitantemente, em uma estrutura autopoiética voltada aos interesses corporativos de classes políticas e administrativas que compõem sua estrutura. Quanto à sociedade, esta se encontra imersa nos valores da pósmodernidade, no egoísmo, no individualismo e na busca da felicidade baseada fundamentalmente em bens materiais voláteis e relações pessoais efêmeras. Tal Estado, na busca de recursos para cumprir suas obrigações originárias, necessita de recursos, os quais devem ser buscados nos bolsos das pessoas que o compõe, devendo, na arrecadação, na gestão e na aplicação dos valores, buscar sua legitimidade no princípio da solidariedade. A partir de tais percepções, nota-se que a Constituição fornece meios suficientes para a implementação de políticas públicas que busquem a efetivação da justiça social, nota-se que os reais empecilhos são a privatização do Estado pela ideologia neoliberal somada a uma estrutura que, antes de objetivar o seu público alvo, o povo brasileiro, objetiva a si mesma, preferenciando o corporativismo ao bem-comum, complementando-se, ditos empecilhos, com os valores pós-modernos que permeiam a sociedade, principalmente no tocante ao egoísmo, ao individualismo e à priorização quase absoluta da busca da felicidade em bens materiais e em relações pessoais superficiais e voltadas a interesses econômicos e financeiros. E, para levar a termo o presente artigo, foram utilizados os métodos histórico, empírico e indutivo, priorizando-se uma visão sistêmica de enfoque do mundo dos fatos e do mundo formal das normas constitucionais.

Palavras-chave: Globalização. Inclusão social. Neoliberalismo. Políticas públicas financeiras e tributárias. Pós-Modernidade. Solidariedade.

\section{INITIAL CONSIDERATIONS}

The aim of this text is to briefly analyze the topics covered in the courses: "Tax and Financial Policies" and "Equality and Contractual Freedom in Labor Law," which are part of the Post-Graduation Program (PPGD) at UNISC. The first goal is to understand the internal and external environments of individuals in a world in which the phenomenon of globalization, allied to the neoliberalism ideology, forged national policies as well as individual and social values. Secondly, the text aims to identify, in the face of such perceptions, which ones, in theory, are the main reasons for the crisis, which crosses the Brazilian State in current days, opposing the formal content of the Constitution to the factual reality that structure the current state of being in the country.

Therefore, the historical, empirical and inductive methods are valid, since the contents are sought in order to characterize the human being within a dynamic context, by visualizing the realities that permeate the critical sense among the actors who experience and observe the current reality, which is present in several writings pieces by numerous authors, allowing a conclusion to be reached from the specificities.

For this attempt, the article begins by describing the postmodern individual, searching for elements in the fields of sociology and psychology in order to assess their values and relations with the environment and with themselves. Thereafter, it is given a step towards the constitutional characterization of Brazil as a capitalist State and its neoliberal reality, which, at minimum, questions the characterization of this country as a "Democratic Law" one, adding two important characteristics historically present in the relations among State-individuals (natural and legal people), which are welfare and clientelism.

Afterwards, the present text focuses on the theme of development and social inclusion, seeking to expose the Republican, Federative and Solidarity principles, describing them and giving 
them its due importance, as principles which contents formally characterize Brazil, the Brazil of what must be, and the Brazil the that should be in terms of materials.

Therefore, within some conceptual basis, the text finally enters into the area of financial and tax policies, directing its discourse towards a vision lined with solidarity and with the need of perceiving such policies from the perspective of income distribution, thus overpassing the current idea based on the need for connection and equivalent/proportional counterpart by the State to whom pays a tribute, especially with regard to taxes. Furthermore, the necessity for this constitutional principle content to encompass the relationships in the world of work is also highlighted.

\section{THE INDIVIDUALS AND THEIR WORLDS}

The postmodern individual is self-centered and unceasingly boosts immediate and disposable dreams of pleasures, which clearly demonstrates a sort of contempt for goods that money cannot buy. The affective and spiritual relations are relativized to the point of becoming an exchange currency, a simple commodity. Selfishness and vanity become prominent attributes of the ones who pursue the eternization of values which are only related to possession and appearance.

Like a child with new toys, the pleasure lasts as long as the feeling of novelty does, which, afterwards, arouses frustration; and in order to eliminate this frustration a new toy is demanded, thus creating an endless succession. Therefore, pleasure and satisfaction are pursued through a senseless voluptuousness of those who do not realize that it is absolutely impossible to be "happy" for every moment of one's life. People tend to look for the well-being through external essences, as if pleasure could be found in an object or in another person's virtue instead of inside the one who looks for it.

This external search disturbs their minds even more, since they become increasingly closed inside themselves by not finding in the external environment what they should seek in their intimate. Consequently, feelings such as hurt, rancor and hate emerge, making these people blame others for not providing what they do not have themselves.

Those feelings lead to a sense of loneliness, and in order to seek refuge to fill time lapses, people use "social masks" to avoid violating the pattern defined by the arbitrary sense of "social duty" imposed by some social segments (and accepted by many others) excluding, the same way they throw garbage away, those who do not accept being puppets of a play where the buffoon laughs at his own financial, intellectual or moral misery.

As a result, the disposition of values is followed by the disposition of obsolete people in a feedback system based on an economic system that buys freedom by making it its flag, by imposing consumption patterns, and by weakening education systems as well as turning the media an empire of values poor of human solidity. Such values are measured in dollar signs and even in the uselessness of creative leisure.

Under these circumstances, the last "nickel" of disadvantaged/poor people, their remaining cents, have been taken away by the "need" of extra minutes for the prepaid telephony. As for the time, it seems to be daily stolen by WhatsApp and Facebook, expiring precious periods of readings, studies, dating and face-to-face relationships. Those platforms sell the false illusion of non-solitude, which 
Public financial/tax policies for social inclusion and the world of work: a ride between post-modern values, factual realities and

makes more and more people to know less about themselves and about factual social realities and their necessary intersections.

It remains the perception that social reforms which are absolutely necessary in terms of material equality do not need constitutional support, as will be discussed forward. It is fundamental, instead, a profound change in the way of thinking and feeling a world consolidated over the individual in his/her relations with him/herself and with his surroundings.

\section{CAPITALISM, NEOLIBERALISM AND CLIENTELY}

First of all, it is important to point out that Brazil, in its constitutional focus, is surely attached to the capitalist economic system. A system whose main foundations are easily found on the following four devices: a) free initiative (article 1, item IV); B) existence and maintenance of different social classes (article 3,item III); C) private property (article 5, item XXII); D) free market competition (article 170, item IV).

In addition to this reality based on the Federal Constitution, it should be noted that, when confronting a formal discourse of "Democratic State of Law", what is actually seen in the national reality, is a Neoliberalism empire. This contrast between real and formal cannot be overlooked under any circumstances.

The imposition of great capital over the State is observed simply by focusing on the intermittent financing that the second gives to the first, whether through donations of land and infrastructure, public financing (BNDES, Brazilian Development Bank, for example) charging interest below the market through renegotiations, exemptions, amnesties, tax remissions, etc.

Moreover, there are recent scandals involving large companies and the Union added to other corruptive practices at various federation levels, which have been daily revealed to the Brazilian society.

Clientelism and assistance can be noticed not only as practices linked to natural persons, but also its great reach at legal entities. An astonishing capitalism is observed on the discourse of those against State interventions, who seek to reach their working capital through the public money as well as their fixed assets and all the pleasing economic-financial favors.

Naturally, as it is known, "thinking" the state must give everything to everyone is part of popular culture. However, the State, specifically in case of Brazil, does not generate its own resources (only a small amount), but rather obtain them through the pockets of its population by collecting direct or indirect taxation.

Important elements are forgotten, such as nothing is for free, someone pays the tuition to those who study in Federal Universities and Pubic ones, someone pays for the "free" medicines, for public nurseries, and for all the services, goods and works provided by the State. Obviously, the ones who pay for those services is the Brazilian population (saying that the State is responsible in mimicking the reality). 
Clientelism and assistentance, in addition to postmodernity individualism and other characteristics from psychological or sociological basis, show that the effectiveness of material equality described in the Constitution in the third section of the Article 3 (to eradicate poverty and substandard living conditions and to reduce social and regional inequalities) requires more than laws, it is necessary to go beyond common sense and rescue social values by restoring the established culture.

\section{DEVELOPMENT AND SOCIAL INCLUSION: A MATTER OF PRINCIPLES}

The word development is used concerning the improvement over the population quality of life as a whole, to the full extent of rights and guarantees stablished in the Constitution without any exclusion.

Regarding inclusion, its basis is absolutely solid as mentioned on section III of the Article 3 , which presents as fundamental objectives the eradication of poverty, approached in this article through its economic/financial aspect, since other miseries do not depend only on money, but also on education, information, access to diverse cultural knowledge, etc.

The end of substandard living conditions is understood in its broadest sense for including racial, gender, belief, other misery issues, etc. Reducing social inequalities, turning the differences between social classes smaller and more just, without, however, eliminating them, respecting individuals multiple characteristics; and reducing regional inequalities, which requires a macro planning and concrete definition of each region, since a regional reality can be the same in Municipalities of different States (one State can have different Municipalities belonging to totally different regions) - regional realities should not be understood as the political map of Brazil.

Although everything is expressed in the $\mathrm{FC}$, it is important to densify its contents through an organic reading according to the principles, which provide unicity and coherence for the constitutional discourse following the contents of Republic, Federation and Solidarity as primary guiding principles in this article.

Undoubtedly, the Republic, due to the solidity of its pillars, is the most important theoretical basis of the Brazilian Constitutional State.

The Republic has its roots in morality and in the exclusion of the will power; thus, not complying with any possibility of corruption or with handing over the state management to the big capital. It also does not align with coalitional presidentialism or with the transformation of the state bureaucracy into an end in itself, making the State become an autopoietic structure of different corporate networks of the most varied public sectors, elective or not, of the three branches of the government, and not an instrument at the service of its population (although supported by its work).

The Republic finds, in the possibility/duty of accountability of its agents, the precise instrument to maintain its efficiency and effectiveness, either in terms of the services provided/construction works, or in the control of public expenditure or in the correct management of assets and of all financial resources (collection, maintenance and disposal). 
Public financial/tax policies for social inclusion and the world of work: a ride between post-modern values, factual realities and

It becomes visible through the absolute publicity of its actions and through its deep respect for freedom of the press, as well as in constitutional conviviality with its own "departments" (Federal Police and the Public Ministry, for example).

It also becomes visible when it makes the public bidding an effective search tool to find the best quality and the best price.

Among many different causes, the Republic crystalizes due to the following reasons: election of political offices, existence of public tenders, periodicity of the mandates, attachment to popular sovereignty, adoption of 'checks and balances' mechanism, possibility of revoking the mandates, and observance of the legality and inviolability of civil liberties.

However, among many qualities that characterize the Republic, a specific one deserves special attention for the purposes of this paper: the demand for equal conditions that must precede any "meritocratic" discourse.

As already seen, the Federal Constitution (FC) does not seek the eradication of social classes, but reinforces that social differences must continue to exist; however, in a way that no poverty exists. In addition, as determined by subsection III of the first Article (human dignity), the poorer must have access to any fundamental rights and they should not be marginalized for any reason whatsoever.

When it comes to equal conditions, every Brazilian person should have equal opportunities (quality in terms of formal education, access to health, etc.) to allow them to apply for different types of jobs and different earnings. In order to do so, it is highly fundamental that every child receives, since the day they were born, all the attention and care that any wealthier child receives.

In order to ensure these rights, the State must act as a social instrument, trying to find equality for the ones who are not seen nor treated like equals. Following this idea, when people finish school, they must have equal conditions to define what to to in their future. The action of the State must ensure the access to higher education, with no cost whatsoever for those who cannot afford it, but still can equally compete. Only after these measures have been taken, it will be possible to talk about merit; because the ones that are equal among themselves should compete with the ones who had not been seen and treated as equals so far. This is the minimum amount of equity in a republic. Without this, there is no equality and there is no republic - let alone a democratic state.

Moreover, in an actual republic, it is necessary a compelling view for sustainability in public and private actions, bearing in mind that sustainability seeks its foundations in the ideal of Solidarity and Fraternity. Solidarity and Fraternity towards present and future generations, which does comply with individualistic and egotistical views of the world.

The State cannot be conceived only through its present components. It could be said, on this aspect, that the state is not (or should not be) seen as certain people inhabiting a given area in a given period of time. The State must extend its existence and its temporal sense in the search of its past history in its present reality and in the future of the current generations and of the generations to come (people who have not been born yet should be already seen as part of the civilization that composes the Nation, which implies rethinking the idea of the acquired rights, since they force the ones who will be born in the future to pay the privileges of those who preceded them). 
The State will never be a Nation, within a sociological context, while it insists on treating and seeing sustainability as something which is only related to the population that exists in the present moment. The Republic puts its feet in morality, which means that there is no Republic when Solidarity is absent, even for those still to be conceived.

In Brazil, unfortunately, Republic is a programmatic clause.

Further developing this idea, the Republic, in a continental country, does not survive without a federative system that is based on balance and cooperation, seeking the construction of a Nation, which the Brazilian State is only when artificially analyzing that Nation and State as synonyms.

The federalism that is desired is precisely what is present in the Federal Constitution; which, unfortunately, is only a formal reality, not a material one, as stated about the Democratic State of Law itself.

Thus, it is possible to start with the reading of the constitutional preamble, highlighting the terms equality, fraternal society and social harmony and adding to them all the content from the third article, which must be the development of a free, fair and solidary society, the assurance of national development, the eradication of poverty and marginalization, the reduction of social and regional inequalities, and, finally, the promotion of every single person's welfare, without any discrimination or differentiation.

Notice that such dispositions apply to every Brazilian citizen, regardless of the place where they live in the country.

The item 9 of the article 21 defines as the Union's competence the need for developing and implementing national and regional territorial plans as well as ensuring social and economical development. The sole paragraph of the article 23 affirms that the federated entities have to assign, through complementary laws, standards for cooperation between them, with the aim of balancing the development and the welfare at a national level.

Following the same line of reasoning, the first item of the article 174 makes it extremely clear that the law must define the guidelines and bases of a balanced national development planning, which must incorporate and make national and regional development plans compatible.

Public consortia and cooperation agreements between federated entities, governed by themselves, are stablished by the article 241. Cooperation, a term that is replicated by the item 9 (cooperation between nations for the progress of the humanity) when it comes to the principles that must guide the national State regarding its international relations.

Now, if the progress of humanity must be sought through cooperation between peoples within an international scope, what about the way of co-existing of the States and Municipalities that compose the Brazilian scenario?

The Constitution, based on a systematic reading of the mentioned parts, is clear; the Federalism in the Constitution is the cooperative one, and the Union should act as an implementer, coordinator and inspector of this Constitution, demanding the implementation of a national plan that seeks the development and social inclusion of all Brazilians, which means the non-atomization of the federation, but the agglutination of differences in search of a single purpose: the welfare, a concrete implementation of the principles of human dignity for everyone who inhabits the country. 
Public financial/tax policies for social inclusion and the world of work: a ride between post-modern values, factual realities and

It is a constitutional determination, and not the current reality - which is dominated by fiscal wars and migrations of dignities, massacring the goal and fundamental principle denominated Solidarity and, perhaps worse, bringing to light all the fragility of the so-called Fraternity, which, due to the post-modern individualism, to the issues brought up by the neoliberalism and to State omissions, dies a little more each day.

However, Solidarity, which is a principle that gives cohesion to the Republican and Federative guidelines, seen not as a human value, but as a constitutional imposition, unlike Fraternity, which is an individual feeling that permeates (or does not) the action and the being of each individual, at a certain extent.

In the absence of Solidarity, there is no constitutional basis for social development and inclusion, after all, the search for a service for the least favored involves the unequal treatment of the unequal. Someone has to contribute more and use less, this is the imposition that becomes necessary.

If everyone had free access to medicines, no one would have access at all. But those who have financial resources can buy them, leaving without medicines those who cannot.

Universal and free access to health can not be imposed as an absolute dogma, it must be read with, at least, the principle of material equality. If it is done this way, it will be relativized, however, if it is not so, what is arranged in the paragraph immediately above will happen.

We must reinforce this idea: nothing comes for free. Life in society requires an unequal treatment of the unequal; otherwise, society itself is in a situation of autophagy, bringing to an end what is meant by civilization.

Thus, the present chapter is concluded with basis to talk about public policies that are sought to implement, even partially, development and social inclusion actions, mainly through financial and tax mechanisms.

\section{FINANCIAL AND TAX POLICIES FOR DEVELOPMENT AND SOCIAL INCLUSION}

The expression "public policies" implies taking into account that the State must make use of actions that make it possible to carry out its social function, which is the search for the common good, which implies in the search of dignified living conditions for every Brazilian person, which necessarily entails an action aimed at the development and social inclusion.

Within this context, it is understood that "financial and tax policies", both in their fiscal function and in their extra-fiscal aspect, are seen as excellent auxiliary means to the attainment of the state function, mainly within a retrenched Federative Republic, constitutionally, by the principle of Solidarity.

It is valid to remember that Financial Law encompasses the collection, management and allocation of resources, whether these resources are taxable or non-taxable. The Tax Law, in its turn, in a simplified way, takes care of the normalization of taxes, which are divided into five types: taxes, fees, improvement contributions, compulsory loans and special contributions.

Fiscal and extra-fiscal functions diverge from the almost unanimous doctrinal. It is not apparent that they are characteristics that are more or less attached to a certain type of tax or to a 
particular kind of tax; it is understood that taxation and extra taxation are possible options for the best management of a given public policy, according to the view of a given public administrator.

Taxation seeks only the collection in the way it is desired with the Income Tax; but in some cases of the terminally ill (here we can see the extra taxation) an exemption is possible. The ICMS (Services and Merchandises Circulation Tax) is the most important tax for the collection of the Member States, but it is often used as an extra-fiscal mechanism, as in the case of fiscal wars. The same happens to the IPI (Brazilian federal excise tax), or does anyone remember their reduction for buying new cars and appliances of the white line?

The goal of the extra taxation is not the collection, but the search for a benefit that, for example, attracts companies, dismisses certain people (due to age, salary and ownership of a single property - where the person lives in) from paying the IPTU (municipal property tax) of a property that has an urban destination, or from paying the ICMS and the IPI when buying cars for people with some specific physical need who can be covered by such benefit; and may also seek a not to do due to the discouragement carried out by the increase of the tribute, which is what happens in relation to the cigarette.

However, regardless of the policy pursued, it is necessary to stress that the main principle underlying taxation is the principle of Solidarity, and that one of the main objectives of taxation is the distribution of incomes through, for instance, special programs, whatever they are, as long as they are morally and legally proven and destined to the development and social inclusion.

The common view that the payment of a tribute requires a give and take principle is, therefore, impossible. The taxes, fundamentally, are not bound and, much less, intended to give a specific counterpart to the ones who paid them.

Therefore, it is logical that those who are most financially and patrimonially fortunate should bear a higher tax burden, ensuring the provisions of Section III of the third article of the Federal Constitution, preferentially establishing, for all types of taxes, changing the constitutional body if necessary, the system of progressive rates - since proportional aliquots, after all, are much more costly than those in lower income areas, which even affects the beneficiaries of the Bolsa Família (Family Allowance), because part of it is returned to the State, in the form of a tribute, every time the value is converted into some kind of good or service.

Even when agreeing with the facts that we have exposed so far, some people will ask: are there no limits to taxation for those who can and should pay more?

There are, obviously. And among those, it is possible to list the principles of legality, equality, non-retroactivity, anteriority and nonagesimal anteriority, but, fundamentally, the principles of the prohibition of the use of tribute with confiscatory effects and, specifically regarding taxes, the principles of economic capacity of the taxpayer, and the limit given by the existential minimum (this in relation to the absolutely poor ones) can still be remembered.

Regarding the prohibition of the confiscatory effect, it is difficult to stablish a limit on each tax, since the legislation itself does not do so, leaving the decision of each case to the Judiciary.

However, more clarity could be given regarding property taxes, such as the IPTU (municipal property tax), the ITR (quarterly financial statements) and the IPVA (automobile taxes), taking into 
account the value of each property and the value of the tax levied, although, even so, subjectivity precludes final certainties. Regarding production and commercialization taxes, it could be said that the limit is the one which prevents its production or circulation.

It could also be said that no tribute should reach or exceed the $100 \%$ rate barrier. However, taxation on cigarettes exceeds $300 \%$.

It is difficult, only case by case and, to make it worse, the confiscatory effect is sought only in relation to each tribute, in isolation, ignoring the rest of the tax burden, which is originated from several federated entities, which is borne by each person, natural or legal.

Here, a monstrous defect of the Federation is perceived. Each federated entity taxes independently, indifferent to the tax burden imposed by the other federated entities. This is a point to be analyzed by a future tax reform.

As for economic capacity, mentioned by many as financial capacity, the Federal Constitution imposes only the taxes with the addendum "whenever possible," which has hindered the unequal treatment of taxpayers who are in unequal situations, because it takes into account the obsolete classification of personal and real taxes, which has been preventing the advance of progressive rates for most taxes.

And, when its use is feasible, as in the case of the Income Tax, it is possible to see a table that is completely outdated and that does not seek a proper treatment of taxpayers whatsoever, thus, favoring those of very high income, fact that hurts the tax morality.

As for the existential minimum, the great difficulty is its conceptualization, bearing in mind the huge number of authors who, at the same time, equalize their content with the content of human, which significantly hampers the dialogue between the two expressions and the quest for its realization.

In this paper, the existential minimum is seen as an expression that characterizes those who are at the top of the poverty line, where it would be possible to find the ones covered by Bolsa Família, because in a completely coherent and prudent way, it is not possible to affirm that they live in decent conditions, mainly because they can barely feed themselves, let alone live with dignity. Therefore, they are, undoubtedly, in an existential minimum condition.

They could not be taxed, yet, they are. And they are taxed through what is called indirect taxes, which are the ones taxed on the final price of good or service (IPI and ICMS, for instance) and the ones that are borne by the final consumer (taxpayer in fact), leaving to the entrepreneur (rightful taxpayer) to pass on this value (paid, in fact, by the final consumer) to the State.

Likewise, going a little beyond, it is understood that the ones who only have enough to live with a little dignity under the terms of the Federal Constitution should not be taxed, although in a more favorable condition than the ones found in the existential minimum, because taxation can take away from them the minimum that is necessary to survive and make them go back to extreme poverty.

It is possible to affirm that, respecting constitutional limits, it is the State's obligation to intervene in social and economic orders, making financial and tax inductive rules that allow stimulus or discouragement; even because minimum state (of few or no participation in economic activity) should not be confused with a non-intervening State. 


\section{FINAL REMARKS}

Taking a detour from the sequence of this text, we would rather emphasize, as a background theme, the imperative need to break with the perception that some Brazilians are more important than others because they inhabit a certain State or Municipality in which the visualizer resides; the ones that, sometimes, refusing to get out of their comfort zone, accept that others, geographically more distant, should suffer the hardships of hunger, intolerance and lack of a better perspective for their future; caring only for their own well-being and for those around them in comradely conditions, fueling the discourse that culture and place of residence make some people better than others.

It is necessary to renegotiate the Brazilian Federation, in the ways imposed by the Federal Constitution, which means that it is substantial to implement a Cooperative Federalism, both in its vertical and horizontal sense.

Such federalism model comes from the republican content itself, where morality is the master rule and the pursuit of the development and social inclusion, seeking material equality for all Brazilians, is an imposition.

Everything dwarfed by the black and white lines of Solidarity.

Therefore, it is imposed to the State to be seen as an instrument and not as an end in itself in concomitance with the interests of the Market. Due to their duties, they have many obligations to fulfill. It is incumbent on the State to comply with the Constitution from a reading that is centered on the contents of solidarity, of the Republic and of the dictates of a real Democratic State of Law, because Brazil needs actions aimed at its population and not at the large capital, to the promotion of its own bureaucracy or to policies aimed at gaining power and maintaining it.

The State is urgently required to draw up and implement public policies that seek development and social inclusion.

Public policies that, necessarily, will go through the need of resources. Public policies that will need to use practices and possibilities linked to the areas of Financial Law and Tax Law.

And for that, it is imperative to break with the individualistic and selfish view that permeates common sense, which seeks to believe in the lie that the State should give each person according to the the exact amount of taxes that each one pays.

It is hard to believe that many people refuse to understand the principle of material equality, which, in order to find solidity and effectiveness, requires the unequal treatment of the unequal.

Yes, public financial and tax policies of development and social inclusion will have to seek resources in the pockets of those who have more income and more equity; otherwise, any initiative or idea that seeks to eradicate poverty and marginalization and reduce social and regional inequalities will be impossible.

The equality of conditions to compete for better jobs and incomes will only become possible by the contribution of resources in the dignification of the non-worthy, which matters in the search of such resources somewhere. The State, as it has been said, does not generate resources. What generates the resources is its population, which means that, in fact, the cost will necessarily be borne by those who have more income and equity. This fact implies, out of respect for those who must contribute the 
most, in the consistent obedience of the constitutional principles that protect the taxpayer, bearing in mind that tax morality, within a republican bias, requires just enough for state actions is collected, demanding equal morality in the handling and allocation of collected amounts.

Summing up, after all that has been said, it is possible to notice that there are no constitutional obstacles, but these obstacles are of other orders, mainly by the construction of an autopoietic structure of the State, which, due to its corporatism, has become an end in itself due to neoliberal impositions and due to the disseminated values of the postmodernity in the current culture, which adds individualism and patronage to welfare.

\section{REFERÊNCIAS}

AGRA, Walber de Moura. Republicanismo. Porto Alegre: Livraria do Advogado, 2005.

BAUMAN, Zygmunt. Modernidade líquida. Rio de Janeiro: Jorge Zahar, 2001.

. O mal-estar da pós-modernidade. Rio de Janeiro: Jorge Zahar, 1998.

A riqueza de poucos beneficia todos n's? Rio de Janeiro: Jorge Zahar, 2015.

BERCOVICl, Gilberto. Dilemas do Estado federal brasileiro. Porto Alegre: Livraria do Advogado, 2004.

BOLESINA, luri; LEAL, Mônia Clarissa Hennig. O mínimo existencial e o controle jurisdicional de políticas públicas: análise de sua operacionalidade na jurisprudência do Supremo Tribunal Federal e do Superior Tribunal de Justiça. Curitiba: Multideia, 2013.

BUFFON, Marciano. Tributação e dignidade humana: entre os direitos e os deveres fundamentais. Porto Alegre: Livraria do Advogado, 2009.

CANAZARO, Fábio. Essencialidade tributária. Igualdade, capacidade contributiva e extrafiscalidade na tributação sobre o consumo. Porto Alegre: Livraria do Advogado, 2015.

CANOTILHO, J. J. Gomes. Direito Constitucional e Teoria da Constituição. 7. ed. Coimbra: Almedina.

CAPRA, Fritjof. O ponto de mutação: a ciência, a sociedade e a cultura emergente. Trad.: Newton Roberval Eichemberg. 22. ed. São Paulo: Cultrix.

CARRAZZA, Roque Antonio. Curso de direito constitucional tributário. São Paulo: Malheiros, 2013.

CASTILHO, Paulo Cesar Baria de. Confisco tributário. Porto Alegre: Revista dos Tribunais, 2002.

CONTI, José, Maurício. Princípios tributários da capacidade contributiva e da progressividade. São Paulo: Dialética, 1997.

CORDEIRO, Karine d Silva. Direitos fundamentais sociais: dignidade da pessoa humana e mínimo existencial - o papel do Poder Judiciário. Porto Alegre: Livraria do Advogado, 2012.

CORRÊA, Darcísio. A construção da cidadania: reflexões histórico-políticas. ljuí: Unijuí, 1999.

GORCZEVSKI, Clovis. Direitos humanos, educação e cidadania: conhecer, educar, praticar. Santa Cruz do Sul: Edunisc, 2009.

GRECO, Marco Aurélio; GODOI, Marciano Seabra (Coord.). Solidariedade Social e Tributação. São Paulo: Dialética, 2005.

GRAU, Eros Roberto. A ordem econômica na Constituição de 1988. 16. ed. São Paulo: Malheiros, 2014.

KRELL, Andreas Joachim. O município no Brasil e na Alemanha: direito e administração pública comparados. São Paulo: Oficina Municipal: 2003. 
Leis de normas gerais, regulamentação do Poder Executivo e cooperação intergovernamental em tempos de reforma federativa. Belo Horizonte: Editora Fórum: 2008.

MATURANA, Humberto R.; VARELA, Francisco J. A árvore do conhecimento: as bases biológicas da compreensão humana. Trad.: Humberto Mariotti e Lia Diskin. São Paulo: Palas Athena, 2001.

MÜLLER, Friedrich. Métodos de trabalho do Direito Constitucional. Trad.: Peter Naumann. 2. ed. São Paulo: Max Limonad, 2000.

Direito, linguagem, violência: elementos de uma teoria constitucional, I. Trad.: Peter Naumann. Porto Alegre: Sergio Antonio Fabris Editor, 1995.

. Teoria estruturante do direito. Trad.: Peter Naumann, Eurides Avance de Souza. 3. ed. Porto Alegre: Revista dos Tribunais, 2011.

. O novo pardigma do direito: introdução à teoria e metódica estruturantes. 3. ed. Porto Alegre: Revista dos Tribunais, 2013.

REVERBEL, Carlos Eduardo Dieder. O federalismo numa visão tridimensional do direito. Porto Alegre: Livraria do Advogado, 2012.

SCHOUERI, Luís Eduardo. Normas tributárias indutoras e intervenção econômica. Rio de Janeiro: Forense, 2005.

TIPKE, Klaus. Moral tributária do estado e dos contribuintes. Trad.: Luiz Dória Furquim. Porto Alegre: Sergio Antonio Fabris, 2012.

. YAMASHITA, Douglas. Justiça fiscal e princípio da capacidade contributiva. São Paulo: Malheiros, 2002.

TORRES, Ricardo Lobo. Tratado de direito constitucional financeiro e tributário - os direitos humanos e a tributação: imunidades e isonomia. 3. ed. Volume III. Rio de Janeiro: Renovar, 2005.

\section{COMO CITAR ESSE DOCUMENTO:}

MACHADO, Raimar Rodrigues; RODRIGUES, Hugo Thamir. Public financial/tax policies for social inclusion and the world of work: a ride between post-modern values, factual realities and the constitutional universe. Revista do Direito, Santa Cruz do Sul, v. 3, n. 50, p. 3-15, set. 2016. ISSN 1982-9957. Disponível em: <https://online.unisc.br/seer/index.php/direito/article/view/8689>. Acesso em: . doi:http://dx.doi.org/10.17058/rdunisc.v3i50.8689. 